\title{
Considerations for development of therapies for cutaneous neurofibroma
}

Sharad K. Verma, PhD, Vincent M. Riccardi, MD, MBA, Scott R. Plotkin, MD, PhD, Hubert Weinberg, MD, R. Rox Anderson, MD, Jaishri O. Blakeley, MD, Kurt Jarnagin, PhD, and James Lee, MD, PhD

Neurology ${ }^{\circledR}$ 2018;91 (Suppl 1):S21-S30. doi:10.1212/WNL.0000000000005791

\section{Abstract}

\section{Objective}

The only therapies currently available for cutaneous neurofibromas (cNF) are procedural. The goals of the Therapies Development Working Group were to (1) summarize currently available treatment options for $\mathrm{cNF},(2)$ define key considerations for drug discovery and development generally, and specifically for $\mathrm{cNF}$, and (3) outline recommendations for the successful development of medical therapies for $\mathrm{cNF}$.

\section{Methods}

The subgroup reviewed published and unpublished data on procedural, drug/device, and medical treatment approaches utilized for $\mathrm{cNFs}$ via literature search. The team defined diseaseand patient-specific factors to consider for therapies development in a series of consensus meetings.

\section{Results}

The team identified 5 approaches entailing procedural and drug/device methods currently under study. There have been 4 clinical studies exploring various interventional therapies, from which outcomes were highly variable. The team identified 4 key factors to prioritize during the development of products for the treatment for cNF: safety, anatomic distribution of cNF, numbers of tumors to be treated, and route of administration.

\section{Conclusions}

The number, size, and distribution of cNF is highly variable among patients with NF1 and it is possible that different phenotypes will require different drug development paths. The nonfatal nature of the disease and relatively limited patient numbers suggest that for any product to have a higher likelihood of acceptance, it will have to (1) demonstrate an effect that is clinically meaningful, (2) have a safety profile conducive to long-term dosing, and (3) have a low manufacturing cost.

\author{
Correspondence \\ Dr. Verma \\ sverma20@jhmi.edu
}

\section{RELATED ARTICLES}

Creating a comprehensive research strategy for cutaneous neurofibromas

Page S1

Cutaneous neurofibromas: Current clinical and pathologic issues

Page S5

The biology of cutaneous neurofibromas: Consensus recommendations for setting research priorities Page S14

Clinical trial design for cutaneous neurofibromas Page S31 


\section{Glossary}

cNF = cutaneous neurofibromas; CTF = Children's Tumor Foundation; NF1 = neurofibromatosis type 1 ; NTAP = Neurofibromatosis Therapeutic Acceleration Program; PDT = photodynamic therapy; VEGF = vascular endothelial growth factor.

The drug discovery and development process is a long, costly, and uncertain enterprise, taking 7-10 years from first-inhuman dosing to approval. ${ }^{1,2}$ This is often preceded by $2-5$ years of preclinical research, where discovery teams comprising experts from biology, chemistry, biochemistry, and drug metabolism and pharmacokinetics seek to validate and pursue targets with pharmacologic association to the disease of interest, and identify molecules that favorably effect disease biology and have optimal properties suitable (and in the case of chemical molecules, patentable) for clinical development. Subsequent to selecting a candidate molecule, multiple safety/toxicology studies are conducted to support the potential testing of the molecule in patients. Furthermore, consideration of the condition and population to be treated, as well as the expected duration of treatment, has a direct effect on the preclinical and early clinical investigations required to bring a drug into clinical trials for a given indication. ${ }^{3}$ Hence, it is advisable to involve patient representatives and disease experts early in the therapeutic development process.

As neurofibromatosis type 1 (NF1)-associated cutaneous neurofibromas (cNFs) are defined as rare with relatively little precedent for drug development targeting these tumors, and likely requiring treatment throughout adulthood, there are even more considerations beyond those mentioned above. ${ }^{3}$ Chief among these include the variability and diversity of the clinical manifestations of cNF. As described in the preceding article in this series by Ortonne et al., ${ }^{4} \mathrm{cNF}$ are variable and diverse with respect to size, location, number, age at presentation, appearance, and symptoms. Each of these factors influences the approaches taken for therapies development and ultimately patient stratification with treatment. To determine potential strategies for the development of targeted therapies also requires a detailed understanding of the key biological factors influencing the formation and maintenance of $\mathrm{cNF}$, as described in the publication by Brosseau et al. ${ }^{5}$ Furthermore, having reproducible and reliable endpoints around which to build clinical trials will be essential to demonstrate clinical success. This has been lacking in many therapeutic studies for $\mathrm{cNF}$ to date (table 1). Hence, efforts are underway to define reproducible and clinically meaningful endpoints for cNF (Cannon et al. ${ }^{6}$ ). Finally, although technically a rare disease, NF1 affects 1:2,500-1:3,500 people ${ }^{7}$ and roughly $99 \%$ of adults with NF1 have cNF. Moreover, patients with NF1 report that treatment of $\mathrm{cNF}$ is a primary concern. Hence, there is a sizeable patient population eager to assist in the discovery and development of therapies for these tumors. By simultaneously exploring the factors necessary for successful drug development in general as well as developing the data necessary to de-risk the investment of time and resources into cNF therapeutics, current efforts will systematically improve the chances of success for the development of medicines for $\mathrm{cNF}$.

\section{Methods}

The Therapies Development Working Group comprised scientific and clinical experts from academic and private sector settings with experience in the discovery and development of therapies primarily for diseases in the skin and nerve, as well as in the care of patients with cNF. This group reviewed published and unpublished results pertaining to drug development for skin-based diseases, and conducted discussions with experts from the surgery and medical device fields, to understand various approaches utilized for the treatment of cNF. The group reviewed and summarized data on existing procedures for treating $\mathrm{cNF}$, drug trials, and endpoints and characteristics of patients enrolled in studies to date. The data were reviewed and discussed across a series of meetings over a 4-month period to prioritize key questions and establish consensus recommendations.

\section{Results}

\section{Current treatments for cNF}

Current clinical management of cNF involves surveillance or some form of procedure-based treatment (table 1). Conventional surgical resection (often termed blade-based) allows for complete removal of the lesions and allows the application of techniques that reduce scarring. This is particularly beneficial for large lesions. There are, however, drawbacks, which include variable scarring (which is influenced by skin type and closure technique), the time required for the procedure and wound healing, and the limited number of lesions that can be treated at a single surgical session.

Alternative approaches have been developed to address these drawbacks, including electrodessication, laser-based treatments (e.g., laser photocoagulation, $\mathrm{CO}_{2}$ laser), radiofrequency ablation, and photodynamic therapy (table 1). While each of these approaches provides possible treatment options for patients, there are several limitations to the trials that have evaluated these methods. These include a lack of detailed enrollment criteria, distinguishing among the different phenotypes of cNF evaluated, comparisons of treated vs untreated areas, duration of follow-up, and standardized endpoints including the use of validated questionnaires for 
Table 1 Treatment trials for NF1 cutaneous neurofibroma

\begin{tabular}{|c|c|c|c|c|c|c|c|}
\hline Treatment (Ref) & $\begin{array}{l}\text { No. of } \\
\text { patients }\end{array}$ & $\begin{array}{l}\text { Age } \\
\text { (y) }\end{array}$ & $\begin{array}{l}\text { Lesion type } \\
\text { treated }\end{array}$ & Size & $\begin{array}{l}\text { Body } \\
\text { location } \\
\text { treated }\end{array}$ & $\begin{array}{l}\text { Primary } \\
\text { end point }\end{array}$ & $\begin{array}{l}\text { Results (study type, average no. } \\
\text { lesions removed or intervention, } \\
\text { outcome) }\end{array}$ \\
\hline $\begin{array}{l}\text { Electrodessication } \\
\text { for multiple cNFs } \\
\text { (8) }\end{array}$ & 97 & $17-68$ & $\begin{array}{l}\text { Flat and } \\
\text { superficial } \\
\text { (sessile to } \\
\text { pedunculated) }\end{array}$ & $\begin{array}{l}<1-10 \\
\mathrm{~cm}\end{array}$ & $\begin{array}{l}\text { Face, neck, } \\
\text { anterior } \\
\text { trunk, arms, } \\
\text { and legs }\end{array}$ & $\begin{array}{l}\text { Patient } \\
\text { satisfaction }^{a}\end{array}$ & - Retrospective study \\
\hline
\end{tabular}

- An average of 450 lesions removed per session

- Outcome: minimal scarring; high patient satisfaction as assessed with

questionnaires with follow-up out to $6 \mathrm{mo}$.

\begin{tabular}{|c|c|c|c|c|c|c|c|}
\hline $\begin{array}{l}\text { Electrodessication } \\
\text { in treating cNF (9) }\end{array}$ & 6 & $27-70$ & $\begin{array}{l}\text { Sessile and } \\
\text { globular } \\
\text { (but not } \\
\text { pedunculated) }\end{array}$ & $\begin{array}{l}\text { Not } \\
\text { reported }\end{array}$ & $\begin{array}{l}\text { Face, neck, } \\
\text { anterior } \\
\text { trunk, arms, } \\
\text { and legs }\end{array}$ & $\begin{array}{l}\text { Patient } \\
\text { satisfaction }^{a}\end{array}$ & - Retrospective study \\
\hline
\end{tabular}

- Several hundreds of lesions removed per session

- Outcome: minimal scarring and high patient satisfaction as measured by improved cosmetic and functional outcome, and nonrecurrence of lesions in the treated areas out to $6 \mathrm{mo}$, based on telephone questionnaires.

\begin{tabular}{|c|c|c|c|c|c|c|}
\hline $\begin{array}{l}\text { Laser } \\
\text { photocoagulation } \\
\text { (surface and } \\
\text { interstitial) for the } \\
\text { removal of }\end{array}$ & 12 & $24-45$ & $\begin{array}{l}\text { Flat and } \\
\text { superficial } \\
\text { (sessile to } \\
\text { pedunculated) }\end{array}$ & $\begin{array}{l}<5 \mathrm{~mm} \\
\text { to }>5 \mathrm{~mm}\end{array}$ & $\begin{array}{l}\text { Face, arms, } \\
\text { and trunk }\end{array}$ & $\begin{array}{l}\text { Lesion } \\
\text { regression and } \\
\text { patient } \\
\text { satisfaction }^{a}\end{array}$ \\
\hline
\end{tabular}

- Retrospective study

removal of

multiple cNFs (11)

- An average of 4 and 10 lesions were removed per session, by surface and interstitial methods, respectively.

- Outcome: $>50 \%$ regression in volume from baseline (measurement technique not reported) for the majority of lesions treated with high patient satisfaction based on patient interviews out to a 14-mo follow-up period.

\begin{tabular}{|c|c|c|c|c|c|c|c|}
\hline $\begin{array}{l}\text { Removal of cNF } \\
\text { using } \mathrm{CO}_{2} \text { laser (12) }\end{array}$ & 106 & $29-55$ & $\begin{array}{l}\text { Sessile to } \\
\text { pedunculated }\end{array}$ & $<1 \mathrm{~cm}$ & $\begin{array}{l}\text { Face, arms, } \\
\text { and trunk }\end{array}$ & $\begin{array}{l}\text { Pain, patient } \\
\text { satisfaction, } \\
\text { and safety }\end{array}$ & - Retrospective study \\
\hline
\end{tabular}

- Average of $>50$ lesions removed in total, with $>5$ lesions removed per session.

- Outcome: assessments for pain and satisfaction conducted by questionnaires asking about pain at each stage (during administration of anesthesia, during laser treatment, and $2 \mathrm{~d}$ after treatment). Favorable response for pain with a mean pain score of $4+2.7$ (numerical rating scale: 0 , no pain; 10 , severe pain) during local anesthesia, and $2.4+2.2$ during laser treatment as well as $2 \mathrm{~d}$ after treatment. Patient satisfaction (numerical score rating scale: 0 , no improvement; 10, major improvement) was $90 \%$, with a mean satisfaction score of $4.6+3.4$. Safety assessments included evaluation of bleeding, infection rates after the procedure, and scar quality.

\begin{tabular}{llllll}
\hline $\begin{array}{l}\text { Radiofrequency } \\
\text { ablation (13) }\end{array}$ & 16 & $16-60$ & $\begin{array}{l}\text { Sessile to } \\
\text { pedunculated }\end{array}$ & $\begin{array}{l}4 \mathrm{~mm} \text { to } \\
10 \mathrm{~cm}\end{array}$ & $\begin{array}{l}\text { Trunk, } \\
\text { upper } \\
\text { extremities, } \\
\text { and face }\end{array}$
\end{tabular}


Table 1 Treatment trials for NF1 cutaneous neurofibroma (continued)

\begin{tabular}{lllllll}
\hline & No. of & Age & Lesion type \\
treatment (Ref) & patients & $\begin{array}{l}\text { (y) } \\
\text { treated }\end{array}$ & Size & $\begin{array}{l}\text { Body } \\
\text { location } \\
\text { treated }\end{array}$ & $\begin{array}{l}\text { Primary } \\
\text { end point }\end{array}$ & $\begin{array}{l}\text { Results (study type, average no. } \\
\text { lesions removed or intervention, } \\
\text { outcome) }\end{array}$
\end{tabular}

- Average of 80 lesions removed per session.

- Outcomes: high patient satisfaction reported by all patients as measured by the Vancouver scar scale (VSS) and patient and observer scar scale (POSAS), in which the average VSS score was 6 points and POSAS was 12 points based on outpatient follow-up out to an average period of $11 \mathrm{mo}$.

\begin{tabular}{llllll}
\hline $\begin{array}{l}\text { Photodynamic } \\
\text { therapy (Phl study) } \\
\text { (NCT01682811) }\end{array}$ & 30 & $\geq 18$ & $\begin{array}{l}\text { Superficial } \\
\text { CNF }\end{array}$ & $\begin{array}{l}<4 \mathrm{~mm} \\
\text { deep }\end{array}$ & $\begin{array}{l}\text { Trunk, } \\
\text { arms, and }\end{array}$
\end{tabular}

- Retrospective study

(NCT01682811)

- Intervention: microneedle-based delivery of ALA (via Levulan Kerastick) and illumination of the treated area.

- Outcomes: photosensitizer uptake by microneedling and a 24-h incubation period, and MTD using red light (630 $\mathrm{nm})$ at $100 \mathrm{~mW} / \mathrm{cm}^{2}$ for $1,000 \mathrm{~s}$, assessing up to 8 lesions per patient in a single treatment session.

\begin{tabular}{|c|c|c|c|c|c|c|c|}
\hline $\begin{array}{l}\text { Photodynamic } \\
\text { therapy (Ph2 } \\
\text { study) } \\
\text { (NCT02728388) }\end{array}$ & 30 & $14-30$ & $\begin{array}{l}\text { Superficial } \\
\text { cNF }\end{array}$ & $\begin{array}{l}<4 \mathrm{~mm} \\
\text { deep }\end{array}$ & $\begin{array}{l}\text { Trunk, } \\
\text { arms, and } \\
\text { legs }\end{array}$ & $\begin{array}{l}\text { Time to } \\
\text { progression } \\
\text { (TTP), defined } \\
\text { as 50\% growth } \\
\text { in size over } \\
\text { baseline } \\
\text { untreated }\end{array}$ & - Prospective study \\
\hline
\end{tabular}

- Intervention: pairs of similar-size lesions will be treated with a photosensitizer (Levulan Kerastick, via microneedling), or placebo (topically) and after $24 \mathrm{~h}$ subjected to illumination with red light (both photosensitizer and placebo) every 4 mo for $3 \mathrm{y}$.

- Outcomes: tumors will be measured by calipers to see whether they are growing more slowly than those with the placebo alone.

\begin{tabular}{|c|c|c|c|c|c|c|c|}
\hline $\begin{array}{l}\text { Ranibizumab } \\
\text { (NCT00657202) }\end{array}$ & 11 & $\geq 18$ & $\begin{array}{l}\text { Sessile to } \\
\text { pedunculated }\end{array}$ & $\begin{array}{l}5-20 \\
\mathrm{~mm}\end{array}$ & $\begin{array}{l}\text { All areas } \\
\text { except face, } \\
\text { scalp, and } \\
\text { groin }\end{array}$ & $\begin{array}{l}\text { Tumor } \\
\text { shrinkage }\end{array}$ & - Retrospective study \\
\hline
\end{tabular}

- Intervention: intratumoral injection into 3 different tumors (1 dose per tumor) once a week for a total of 4 wk ( 4 doses total per tumor) and monitoring posttreatment for $60 \mathrm{~d}$ with physical examination (including photographs of tumors), review of current medications, vital signs, routine blood tests, serum chemistry blood tests, interstitial fluid pressure measurements, and tumor samples.

- Outcomes: highly variable responses with minimal efficacy with respect to tumor shrinkage relative to baseline volume as measured by calipers and photography 
Table 1 Treatment trials for NF1 cutaneous neurofibroma (continued)

\begin{tabular}{|c|c|c|c|c|c|c|c|}
\hline Treatment (Ref) & $\begin{array}{l}\text { No. of } \\
\text { patients }\end{array}$ & $\begin{array}{l}\text { Age } \\
\text { (y) }\end{array}$ & $\begin{array}{l}\text { Lesion type } \\
\text { treated }\end{array}$ & Size & $\begin{array}{l}\text { Body } \\
\text { location } \\
\text { treated }\end{array}$ & $\begin{array}{l}\text { Primary } \\
\text { end point }\end{array}$ & $\begin{array}{l}\text { Results (study type, average no. } \\
\text { lesions removed or intervention, } \\
\text { outcome) }\end{array}$ \\
\hline $\begin{array}{l}\text { Imiquimod } \\
\text { (NCT00865644) }\end{array}$ & 20 & $\geq 18$ & $\begin{array}{l}\text { Sessile to } \\
\text { pedunculated }\end{array}$ & $\begin{array}{l}5 \mathrm{~mm}- \\
30 \mathrm{~mm}\end{array}$ & $\begin{array}{l}\text { Trunk, neck, } \\
\text { or } \\
\text { extremities } \\
\text { (excluding } \\
\text { the hands } \\
\text { and feet) }\end{array}$ & $\begin{array}{l}\text { Tumor } \\
\text { shrinkage }\end{array}$ & - Retrospective study \\
\hline
\end{tabular}

- Intervention: topical application to 3 tumors 5 times per week for 6 wk.

- Outcomes: highly variable responses were observed with minimal efficacy with respect to tumor shrinkage relative to baseline volume as measured by calipers.

\begin{tabular}{|c|c|c|c|c|c|c|c|}
\hline Rapamycin (21) & 28 & $>13$ & Not reported & $\begin{array}{l}\text { Not } \\
\text { reported }\end{array}$ & Face & $\begin{array}{l}\text { Safety of topical } \\
\text { rapamycin }\end{array}$ & - Retrospective study \\
\hline & & & & & & & $\begin{array}{l}\text { - Intervention: topical application of } \\
\text { polyvinylidene fluoride containing 1-5 mg } \\
\text { rapamycin daily for up to } 6 \text { mo. }\end{array}$ \\
\hline
\end{tabular}

- Outcomes: safety with respect to blood chemistry (no significant changes in white blood cell, red blood cell, or platelet counts) and dermatologic sensitivity at the site of application with respect to pain, erythema, edema, and pruritis; however, no detectable systemic absorption of rapamycin (all blood concentrations were $<1.0 \mathrm{ng} / \mathrm{mL}$ ) was observed.

\begin{tabular}{|c|c|c|c|c|c|c|c|}
\hline $\begin{array}{l}\text { Selumetinib } \\
\text { (NCT02839720) }\end{array}$ & 24 & $\geq 18$ & $\begin{array}{l}\text { Superficial } \\
\text { cNF }\end{array}$ & $\begin{array}{l}<3 \mathrm{~mm} \\
\text { deep }\end{array}$ & $\begin{array}{l}\text { Trunk, legs, } \\
\text { and arms }\end{array}$ & $\begin{array}{l}\text { Tumor } \\
\text { shrinkage }\end{array}$ & - Prospective study \\
\hline & & & & & & & $\begin{array}{l}\text { - Selumetinib will be delivered orally } \\
\text { ( } 50 \mathrm{mg} \text { /dose) every } 28 \mathrm{~d} \text { (single cycle) } \\
\text { where efficacy will be assessed based } \\
\text { on tumor shrinkage relative to baseline } \\
\text { volume as measured by calipers and } \\
\text { digital photography (baseline to } 1 \mathrm{y} \text { ). }\end{array}$ \\
\hline & & & & & & & $\begin{array}{l}\text { - Outcomes: a } 20 \% \text { reduction in the } \\
\text { average cNF volume is a minimum } \\
\text { response criterion, and Skindex surveys } \\
\text { to be completed by study participants } \\
\text { before treatment, after the first cycle, } \\
\text { and then after every } 4 \text { cycles of } \\
\text { treatment, and related to cNF volume } \\
\text { measurements to help qualitatively } \\
\text { determine an efficacious cNF volume } \\
\text { reduction. }\end{array}$ \\
\hline
\end{tabular}

${ }^{\text {a }}$ Nonvalidated survey, verbal report.

pain and patient satisfaction. Additional challenges not fully addressed in the literature are the cost and availability of interventions.

Electrodessication is a method in current clinical use that entails tissue desiccation through dehydration and denaturation of the tumor. ${ }^{8,9}$ The primary advantage of this approach is the ability to remove large numbers (hundreds to thousands) of lesions in a single procedure over a couple of hours. The limitations are that electrodessication requires the use of general anesthesia, and results in variable scarring, with the rare formation of hypertrophic scarring. ${ }^{10}$ Skin pigmentation changes appear to be a more common effect of electrodessication. Further, the number of centers and expert surgeons or dermatologists offering electrodessication under general anesthesia is limited. Laser photocoagulation uses a nonablative laser to finely cauterize blood vessels. It has been reported to be an effective tool for treatment of small $\mathrm{cNF}^{11}$ $\mathrm{CO}_{2}$ laser ablation has been used for a number of years, in many indications, though only a few reports have evaluated the efficacy of this method in NF1. A retrospective study of 106 patients with multiple small, superficial $(<1 \mathrm{~cm}) \mathrm{cNF}$ treated with $\mathrm{CO}_{2}$ laser was recently reported. ${ }^{12}$ Patient satisfaction as assessed by questionnaires was reported as $>90 \%$, 
with patients reporting improvements in pain and where $94 \%$ of treated patients stated they would use $\mathrm{CO}_{2}$ laser treatment in the future. While encouraging, a larger prospective study is needed to confirm these preliminary results. Radiofrequency ablation, where high energy flux around the electrode tip imparts a localized thermal effect without damage to adjacent local tissue, has also been utilized to treat cNF. ${ }^{13}$ Although the number of patients reported from these studies was smaller, reported outcomes indicate high to very high patient satisfaction as assessed by patient- and observer-based questionnaires, and the ability to remove several lesions ( 80 per session) from different parts of the body. ${ }^{13}$ Photodynamic therapy (PDT) has been utilized in the treatment of certain cancers, and is currently being investigated for superficial cNF. ${ }^{14}$ PDT consists of a binary process entailing selective accumulation of a photosensitizer followed by its lightmediated activation resulting in the generation of reactive oxygen species and subsequent localized tumor cell destruction. A phase I study for cNF using PDT involving topical application of the known photosensitizer aminolevulinic acid and red light established the safety and maximal tolerated dose for this method (NCT01682811), and provided the basis for a single-site phase 2 study targeting adolescents and young adults (ages 14-30) with cNF (NCT02728388). This age range was selected for the phase 2 study as it is hypothesized that this is a life stage associated with accelerated cNF growth, providing an opportunity to prevent or diminish tumor development. Limitations associated with this approach include pain during treatment, achieving a sufficient depth of penetrance, and limited number of lesions that can be treated per session. In order to address depth of penetrance to reach the deeper portion of the cNF lesions, intralesional injection by microneedles accompanied by delivery-driving technologies like iontophoresis has been considered. ${ }^{15}$ In this regard, local drug/device combinations represent an exciting potential approach for cNF. Approaches such as fractional lasers or devices that vaporize tissue to create fenestrations deep into skin to enhance topical delivery are possibilities for therapy delivery to be explored. $^{16}$

While procedural methods look promising, they are not riskfree. In the $\mathrm{CO}_{2}$ laser study, for example, a local infection rate of $15 \%$ was reported. ${ }^{12}$ As noted by the authors of the study, this might be prevented by prophylactic treatment with a short course of periprocedural oral antibiotic treatment. The approaches described above are all in use or being evaluated at various centers around the world, but limited by a lack of prospective data about the short- and long-term adverse events or efficacy (table 1) of treatment.

Going forward, important goals in the field include generating standardized outcome assessments of these approaches regarding their ability to control cNF growth, understanding patterns of regrowth, effects of tumor-associated symptoms, and effects on neighboring skin, all with awareness of the skin type and body region treated and while assessing short- and long-term patient perceived benefit with patient-reported outcomes.

\section{Experimental drug therapies for cNF}

Beyond procedural-based techniques, there have been a few interventional drug trials specifically focused on cNF (table 1). Early work with the histamine 1 receptor inhibitor ketotifen has been explored, exploiting the mast cell stabilization properties of this drug as a means of controlling neurofibroma growth and the associated pain and itch. ${ }^{17-19}$ This treatment showed modest effectiveness in case series and observational studies, but the generation of rigorous modern clinical trial data will be necessary in order to formally evaluate this therapy for $\mathrm{cNF}$.

To target new vessel growth within the cNF tumor, the vascular endothelial growth factor (VEGF) targeting monoclonal antibody ranibizumab was evaluated in a pilot study of patients with $\mathrm{cNF}$ whose lesions were discrete, amenable to measurement with calipers $(5-20 \mathrm{~mm})$ and photographs (NCT00657202). The primary objective was to determine the biologic effect of inhibiting local VEGF on tumor volume. The secondary objectives were to identify angiogenic factors upregulated in cNFs treated with the drug and to conduct correlative studies using immunohistochemistry for angiogenic proteins. Data indicated that there was tremendous variability with respect to tumor volume as assessed with calipers over time (both within and across tumors) limiting data interpretation, and the overall effect of treatment was minimal. It was concluded that intralesional injection is an effective approach for studying tumor biology and potentially for therapeutics for specific lesions, but that the priority is development of validated measurement techniques for $\mathrm{cNF}$ given the observed variability in size assessment with calipers.

The TLR7 agonist imiquimod (5\%) was evaluated in patients with $\mathrm{cNF}$, based on its demonstrated efficacy for actinic keratosis, basal cell carcinoma, and external genital warts (NCT00865644). The primary objective was to assess the effect of topical treatment on tumor volume of cNFs in adults, and the secondary objectives were to correlate inflammatory infiltrate adjacent to treated lesions during treatment with tumor response, and determine the effect on circulating Tregs. By scaling tumors to the mean, a $15 \%$ reduction in volume (as measured by caliper) was observed over 4 months, while the control group had an approximately $10 \%$ reduction in volume, thus there appeared to be little effect on tumor volume with TLR7 agonism. Importantly, physical examination revealed lower than expected rates of skin inflammation after treatment (5\%-10\%), which suggests it may be difficult to generate an immune response against NF1 lesions.

Continuously activated Ras driving unrestrained growth of cells is a central feature of NF1, and so components of the Ras-MEK pathway are logical therapeutic targets for NF1driven tumors. ${ }^{20}$ Repurposing established drugs or development of novel molecules against new targets in these 
pathways are both logical strategies. A study exploring the use of topical rapamycin conducted for the treatment of tuberous sclerosis complex on facial angiofibromas was expanded to include patients with NF1 with $\mathrm{CNF}^{21}{ }^{21}$ This study showed that topical rapamycin applied daily for 6 months resulted in no detectable systemic absorption of rapamycin, and no significant changes in white blood cell, red blood cell, or platelet counts, indicating that low systemic side effects are to be expected with similar topical therapies. ${ }^{21}$ Subsequently, patients with cNF were enrolled for a study of both systemic and topical rapamycin with cNF lesional improvement as assessed by digital photography as the primary endpoint (NCT01031901). Enrollment is completed and data are expected.

The investigational MEK1/2 inhibitor AZD6244 (Selumetinib) has shown activity in a phase 1 study of children with NF1-associated $\mathrm{pNF}^{22}$ Inspired by these results, a study evaluating AZD6244 in adults with NF1 and cNF has recently started, with the primary objective of assessing if the drug can shrink cNF tumors as assessed by calipers (NCT02839720).

Areas yet to be explored for cNF are biologically based drugs, although such approaches are under active investigation for pNF. $^{23}$ One could also consider cNF-specific antigens as potential targets, and the use of cNF-selective antibodies or CAR-modified $\mathrm{T}$ cells configured to recruit the immune system to destroy cNF Schwann cells. ${ }^{24}$ Another approach may be to reduce cNF-directed immunosuppression by identification of important checkpoint blockers in cNF lesions and application of appropriate immune checkpoint blockers. ${ }^{25}$ The identification of cNF selective antigens and cNF checkpoint inhibitors would be a key first step in the process. However, short- and long-term toxicities of such approaches must be considered.

\section{Considerations for therapies development for cNF}

In considering the relatively limited numbers of patients with $\mathrm{cNF}$, the variability of cNF presentation and symptoms, and the likely need for long-term therapy, there are specific considerations pertaining to cNF drug development, including the following (table 2):

1. Safety: cNF are a major source of morbidity for patients with NF1 but are not associated with mortality. While disfigurement, reduced QoL, and restricted social function are devastating for patients with $\mathrm{cNF}^{26,27}$ patients, caregivers, physicians, and regulators may view serious adverse events to be unacceptable for a nonmalignant condition. Thus, new drugs will need to be well-tolerated over long treatment periods with a low frequency of local and systemic side effects.

2. Route of administration: This is an important consideration for cNF, where treatment of hundreds (or thousands) of lesions may be required. While systemic therapy is typically preferred by patients for convenience, this benefit must be weighed against the occurrence of toxicities. Drugs delivered via IV and subcutaneous routes have been approved for other dermatologic conditions; however, these drugs are less convenient for patients and caregivers to administer and are associated with infusion site reactions. Furthermore, such products are very expensive to develop, manufacture, and typically require cold chain storage. Thus there is an overall higher cost of goods. Topical therapies allow localized delivery of a drug to the target lesion, thereby reducing the systemic exposure. However, topical delivery is limited by the cutaneous penetration of the active substance as well as the solubility of the drug in topical formulations. Variable depth of the apparent forms of cNF tumors is another consideration for topical delivery. For example, topical drugs are likely better suited for application to smaller visible areas (i.e., hands, neck, face). For patients with a great many lesions, and in nonvisible areas, a topical delivered medicine may not be ideal.

3. Phenotype: To develop treatments for cNF, the classification, distribution, and size of cNF will be important considerations guiding development of therapeutic approaches. ${ }^{28}$ Additional factors to consider include anatomic location, cNF-associated symptoms,

Table 2 Considerations for therapeutic approaches for cutaneous neurofibromas

\begin{tabular}{llll}
\hline Approach & Advantages & Disadvantages & Ideal phenotype \\
\hline Systemic delivery & Treat entire body & Toxicity & Heavy tumor burden \\
\hline Topical application & Minimize toxicity & Cutaneous penetrance & Limited disease burden \\
\hline Surgical procedure & Minimize toxicity & Difficult to formulate & Limited disease burden \\
\hline & $\begin{array}{l}\text { Can treat many few or many lesions } \\
\text { (depending on procedure used) }\end{array}$ & $\begin{array}{l}\text { Potential for scarring, pigmentation } \\
\text { changes, and recurrence of lesions }\end{array}$ & \\
\hline & & Pain & Access issues for patients \\
\hline
\end{tabular}


age, sex, skin type, and hormone effects, as described in table 3.

4. Goal of treatment: As cNF develop over a lifetime, and have variable functional effects and associated symptoms, treatment approaches may have a range of goals, including prevention of $\mathrm{cNF}$ development, halting the progression of established $\mathrm{cNF}$, relieving $\mathrm{cNF}$ associated symptoms, or regression of the cNF. The goal of the drug being developed should be matched to its mechanism of action and considered throughout preclinical to clinical therapeutic development.

In order to accelerate the development of a drug with the highest likelihood of biologic effect, one promising approach is to test several candidate drugs against several welldefined drug targets via small clinical discovery studies assessing intralesion pharmacokinetic and pharmacodynamic effects across multiple cNF lesion types, skin types, in people of various ages, and in various regions of the body. The goal of this approach is to rapidly rule in or out individual drugs, drug targets, and conditions of use. The best agents from these evaluations could then be advanced to efficacy testing. Such an approach may provide an early proof-of-concept regarding drug mechanism and required concentration, and dosing frequency with low toxicity. Another approach that mitigates the concern about a potential disproportionate risk of systemic therapy (e.g., MEK inhibitor) for benign tumors is to include cNF endpoints in clinical trials designed for other NF1 manifestations such as pNF or malignant peripheral nerve sheath tumors. This is being done to some extent with the ongoing studies assessing MEK inhibitors in adults and children with $\mathrm{pNF}$ in which digital photography is incorporated as an exploratory endpoint (NCT03231306, NCT01362803). As ongoing efforts to define the most accurate and reproducible endpoints for $\mathrm{cNF}$ through groups like the Response Endpoints in Neurofibromatosis and Schwannomatosis (REiNS) International Consortium yield data, it will be increasingly feasible to incorporate assessment of $\mathrm{cNF}$ response into other clinical trials.

\section{Discussion}

In considering cNF from a therapies development standpoint, there are multiple factors to balance, including the goal of treatment, anatomic region, tumor depth and size, short- and long-term toxicity, and the route of administration. Likewise, considerations for clinical trial designs are essential (Cannon et al. ${ }^{6}$ ) For cNF, achieving the requisite balance is complicated not only by the challenges in effectively delivering drug into the deep dermis, but also the high safety margin required for a nonfatal tumor that may require long-term drug exposure. Based on this, a product will have to demonstrate clinically meaningful therapeutic benefit with acceptable safety, and justifiable cost of goods to spur investment in its

Table 3 Additional factors influencing development approaches

\begin{tabular}{ll}
\hline Factor & Effect description \\
$\begin{array}{l}\text { Location and QoL } \\
\text { effect }\end{array}$ & $\begin{array}{l}\text { Locations of cNF tumors, especially in places that are visible (e.g., face), are important to patients. In adults with NF1, } \\
\text { perceived disease visibility and disfigurement is significantly associated with depression, psychosocial distress, QoL } \\
\text { impairment, and negative body experience for attractiveness/self-confidence. For these people, the disease is life- } \\
\text { altering, and potential treatments need to consider the outcomes of lesion treatment, especially in visible anatomic } \\
\text { locations. }\end{array}$
\end{tabular}

Interference Many NF1 cutaneous NFs interfere with normal functions. Among these are the nipple/areola (breastfeeding), the

(mechanical) buttocks and thighs (sitting), wearing certain garments (brassieres), performing fine precision tasks (use of fingers), or walking (soles of feet).

\begin{tabular}{ll}
\hline Itching, pain, & Many persons with cutaneous NF experience disturbing itching (pruritus), pain, and tenderness locally associated \\
tenderness & with all types of cNF tumors.
\end{tabular}

Age and sex The numbers and sizes of NF1 cutaneous neurofibromas increase in adolescence and early adulthood, so $\quad$ 4, 6 enrollment criteria and endpoints must consider the patient's age. Safety and patient capabilities will require the utilization of a product that is suitable for a pediatric population. A pediatric development plan will be required for approval for use in young patients. Preclinical and clinical trials should enroll both sexes.

\begin{tabular}{ll}
\hline Hormone status & Variables to consider include puberty, pregnancy, menopause, and use of hormonal birth control. Hormone \\
receptors, such as progesterone, may represent possible therapeutic targets.
\end{tabular}
receptors, such as progesterone, may represent possible therapeutic targets.

Coincidental Coincidental disorders (psoriasis, actinic keratoses, albinism) and certain normal variants (actinic sensitivity) and environmental exposures (contact sports, sunbathing) are variables that need consideration.

Medications Use of other medications may be potential confounders for assessing the initiation, progression, and treatment of NF1 cNF. Considerations should be made for drugs like corticosteroids, antihistamines, opiate analgesics used to help manage itch or pain, asthma medications, birth control methods, and over-the-counter medications.

Diet/nutrition It is not clear that ordinary or unusual diets are critical confounders of cNF initiation, progression, and treatment, though this remains an area for investigation. Further investigation of the effects of vitamin D may be of interest as preliminary studies have shown that skin mast cells (which are excessive in NF1) sequester cholecalciferol (vitamin $D_{3}$ ), and that low serum calcidiol (vitamin $D_{3}$ metabolite) is associated with NF1 cNF burden.

Abbreviations: cNF = cutaneous neurofibromas; NF1 = neurofibromatosis type 1; QoL = quality of life. 
development. The development of new treatments for $\mathrm{cNF}$ patients will require contributions from scientists, physicians, regulators, patients, patient advocates, and the drug and medical device industry. These groups will need to collaborate to support the funding, discovery, development, manufacturing, and clinical trials. Encouragingly, there are several groups focused on NF1 and closely allied conditions that have already accomplished a great deal to support therapeutic development for cNF. Many of these are listed on the NIH NF rare disease website (rarediseases.info.nih.gov/diseases/7866/neurofibromatosis-type-1), in addition to the websites for the Neurofibromatosis Therapeutic Acceleration Program (NTAP) and the Children's Tumor Foundation (CTF) (n-tap.org/; ctf.org/) and other community resources. Finally, several incentives have been provided by the US Congress to stimulate the development of rare disease therapies, and these may encourage investment in the NF1 community. These benefits include up to 7 years of exclusivity (which may be particularly attractive when a repurposed drug is developed), tax credits for clinical trials costs, waiver of Prescription Drug User Fees, access to grants, and finally, if a pediatric indication is a target, a potential priority review voucher. Through partnership with patients around the world with NF1 organized through the CTF patient registry and collaborative efforts such as the NTAP summit for cNF, we are well-poised to accelerate the development of effective therapies for $\mathrm{cNF}$ in NF1.

\section{Author contributions}

S. Verma: drafting the manuscript, development of recommendations. V.M. Riccardi: contributing to and review of manuscript, development of recommendations. S. Plotkin: review of manuscript, development of recommendations. $\mathrm{H}$. Weinberg: review of manuscript, development of recommendations. R. Rox Anderson: review of manuscript, development of recommendations. J. Blakeley: contributing to and review of manuscript, development of recommendations. K. Jarnagin: contributing to and review of manuscript, development of recommendations. J. Lee: contributing to and review of manuscript, development of recommendations, subgroup leadership.

\section{Acknowledgment}

The authors thank fellow cNF summit participants Naba Bora, Isaac Brownell, Denise Casey, Sally Gottesman, Rhonda Jackson, Pam Knight, Hon Sum Ko, Bruce Korf, Robert Lavker, Salvo LaRosa, Lu Le, Eric Legius, Jill Morris, Michael Parides, Ken Rudd, Marigo Stathis, Brigitte Widemann, and Pierre Wolkenstein for contributions and Ashley Cannon and Dominique Pichard for reviews of this manuscript.

\section{Study funding}

This work was supported by an agreement from The Johns Hopkins University School of Medicine and the Neurofibromatosis Therapeutic Acceleration Program (NTAP). Its contents are solely the responsibilities of the authors and do not necessarily represent the official views of The Johns Hopkins University School of Medicine.

\section{Disclosure}

S. Verma and V. Riccardi report no disclosures relevant to the manuscript. S. Plotkin reports ownership in NFlection and consulting fees from Novartis. H. Weinberg, R. Anderson, J. Blakeley, and $\mathrm{K}$. Jarnagin report no disclosures relevant to the manuscript. J. Lee is a full-time employee of Dermavant Sciences. Go to Neurology.org/N for full disclosures.

Received November 1, 2017. Accepted in final form April 23, 2018.

\section{References}

1. Hay M, Thomas DW, Craighead JL, Economides C, Rosenthal J. Clinical development success rates for investigational drugs. Nat Biotechnol 2014;32:40-51.

2. Mullin R. Tufts study finds big rise in cost of drug development. Chem Eng News 2014:92-96.

3. Uguen D, Lonngren T, Le Cam Y, et al. Accelerating development, registration and access to medicines for rare diseases in the European union through adaptive approaches: features and perspectives. Orphanet J Rare Dis 2014;9:20.

4. Ortonne N, Wolkenstein P, Blakeley JO, et al. Cutaneous neurofibromas: current definitions and pathologic issues. Neurology 2018;91:S5-S13.

5. Brosseau JP, Pichard DC, Legius EH, et al. The biology of cutaneous neurofibromas: consensus recommendations for setting research priorities. Neurology 2018;91: S14-S20

6. Cannon A, Jarnagin $\mathrm{K}$, Korf B, et al. Clinical trial design for cutaneous neurofibromas. Neurology 2018;91:S31-S37.

7. Anderson JL, Gutmann DH. Neurofibromatosis type 1. Handb Clin Neurol 2015; 132:75-86.

8. Levine SM, Levine E, Taub PJ, Weinberg H. Electrosurgical excision technique for the treatment of multiple cutaneous lesions in neurofibromatosis type I. J Plast Reconstr Aesthet Surg 2008;61:958-962.

9. Lutterodt CG, Mohan A, Kirkpatrick N. The use of electrodessication in the treatment of cutaneous neurofibromatosis: a retrospective patient satisfaction outcome assessment. J Plast Reconstr Aesthet Surg 2016;69:765-769.

10. Miyawaki T, Billings B, Har-Shai Y, et al. Multicenter study of wound healing in neurofibromatosis and neurofibroma. J Craniofac Surg 2007;18:1008-1011.

11. Elwakil TF, Samy NA, Elbasiouny MS. Non-excision treatment of multiple cutaneous neurofibromas by laser photocoagulation. Lasers Med Sci 2008;23:301-306.

12. Meni C, Sbidian E, Moreno JC, et al. Treatment of neurofibromas with a carbon dioxide laser: a retrospective cross-sectional study of 106 patients. Dermatology 2015; 230:263-268.

13. Kim SH, Roh SG, Lee NH, Yang KM. Radiofrequency ablation and excision of multiple cutaneous lesions in neurofibromatosis type 1. Arch Plast Surg 2013;40:57-61.

14. Dolmans DE, Fukumura D, Jain RK. Photodynamic therapy for cancer. Nat Rev Cancer 2003;3:380-387.

15. Prausnitz MR, Langer R. Transdermal drug delivery. Nat Biotechnol 2008;26: 1261-1268.

16. Banzhaf CA, Thaysen-Petersen D, Bay C, et al. Fractional laser-assisted drug uptake: impact of time-related topical application to achieve enhanced delivery. Lasers Surg Med 2017;49:348-354

17. Riccardi VM. Mast-cell stabilization to decrease neurofibroma growth. Preliminary experience with ketotifen. Arch Dermatol 1987;123:1011-1016.

18. Riccardi VM. A controlled multiphase trial of ketotifen to minimize neurofibromaassociated pain and itching. Arch Dermatol 1993;129:577-581.

19. Riccardi VM. Ketotifen suppression of NF1 neurofibroma growth over 30 years. Am J Med Genet A 2015;167:1570-1577.

20. Ratner N, Miller SJ. A RASopathy gene commonly mutated in cancer: the neurofibromatosis type 1 tumour suppressor. Nat Rev Cancer 2015;15:290-301.

21. Koenig MK, Hebert AA, Roberson J, et al. Topical rapamycin therapy to alleviate the cutaneous manifestations of tuberous sclerosis complex: a double-blind, randomized, controlled trial to evaluate the safety and efficacy of topically applied rapamycin. Drugs R D 2012;12:121-126.

22. Dombi E, Baldwin A, Marcus LJ, et al. Activity of selumetinib in neurofibromatosis type 1-related plexiform neurofibromas. N Engl J Med 2016;375:2550-2560.

23. Packer RJ, Gutmann DH, Rubenstein A, et al. Plexiform neurofibromas in NF1: toward biologic-based therapy. Neurology 2002;58:1461-1470.

24. Hofmeister V, Vetter C, Schrama D, Brocker EB, Becker JC. Tumor stroma-associated antigens for anti-cancer immunotherapy. Cancer Immunol Immunother 2006;55:481-494.

25. Ribas A. Releasing the brakes on cancer immunotherapy. N Engl J Med 2015;373: 1490-1492.

26. Page PZ, Page GP, Ecosse E, Korf BR, Leplege A, Wolkenstein P. Impact of neurofibromatosis 1 on quality of life: a cross-sectional study of 176 American cases. Am J Med Genet A 2006;140:1893-1898.

27. Wolkenstein P, Zeller J, Revuz J, Ecosse E, Leplege A. Quality-of-life impairment in neurofibromatosis type 1: a cross-sectional study of 128 cases. Arch Dermatol 2001; 137:1421-1425.

28. Karvonen SL, Kallioinen M, Yla-Outinen H, Poyhonen M, Oikarinen A, Peltonen J. Occult neurofibroma and increased $\mathrm{S} 100$ protein in the skin of patients with neurofibromatosis type 1: new insight to the etiopathomechanism of neurofibromas. Arch Dermatol 2000;136:1207-1209. 
29. Roth TM, Petty EM, Barald KF. The role of steroid hormones in the NF1 phenotype: focus on pregnancy. Am J Med Genet A 2008;146A:1624-1633.

30. Dugoff L, Sujansky E. Neurofibromatosis type 1 and pregnancy. Am J Med Genet 1996;66:7-10.

31. Lammert M, Mautner VF, Kluwe L. Do hormonal contraceptives stimulate growth of neurofibromas? A survey on 59 NF1 patients. BMC Cancer 2005;5:16.

32. Sbidian E, Duong TA, Valeyrie-Allanore L, Wolkenstein P. Neurofibromatosis type 1: neurofibromas and sex. Br J Dermatol 2016;174:402-404.
33. McLaughlin ME, Jacks T. Progesterone receptor expression in neurofibromas. Cancer Res 2003;63:752-755.

34. Riccardi VM. Hiding in plain sight: a consideration of NF1-associated hypovitaminosis D and its treatment. J Genet Syndromes Gene Ther 2014;5:223.

35. Silveira SR, Hadler WA. A histochemical investigation on the percutaneous absorption of vitamin D synthesized into the mammal epidermis. Acta Histochem 1985;77:11-18.

36. Silveira SR, Hadler WA. A histochemical study on the vitamin D synthesis into the epidermis. Acta Histochem 1985;76:225-234. 


\section{Neurology}

\section{Considerations for development of therapies for cutaneous neurofibroma}

Sharad K. Verma, Vincent M. Riccardi, Scott R. Plotkin, et al.

Neurology 2018;91;S21-S30

DOI 10.1212/WNL.0000000000005791

\section{This information is current as of July 9, 2018}

\section{Updated Information \& Services}

\section{References}

Citations

Subspecialty Collections

Permissions \& Licensing

\section{Reprints}

including high resolution figures, can be found at: http://n.neurology.org/content/91/2_Supplement_1/S21.full

This article cites 35 articles, 1 of which you can access for free at: http://n.neurology.org/content/91/2_Supplement_1/S21.full\#ref-list-1

This article has been cited by 1 HighWire-hosted articles: http://n.neurology.org/content/91/2_Supplement_1/S21.full\#\#otherartic les

This article, along with others on similar topics, appears in the following collection(s):

Nerve tumor

http://n.neurology.org/cgi/collection/nerve_tumor

Neurofibromatosis

http://n.neurology.org/cgi/collection/neurofibromatosis

Information about reproducing this article in parts (figures,tables) or in its entirety can be found online at:

http://www.neurology.org/about/about_the_journal\#permissions

Information about ordering reprints can be found online:

http://n.neurology.org/subscribers/advertise

Neurology ${ }^{\circledR}$ is the official journal of the American Academy of Neurology. Published continuously since 1951, it is now a weekly with 48 issues per year. Copyright @ 2018 The Author(s). Published by Wolters Kluwer Health, Inc. on behalf of the American Academy of Neurology.. All rights reserved. Print ISSN: 0028-3878. Online ISSN: 1526-632X.

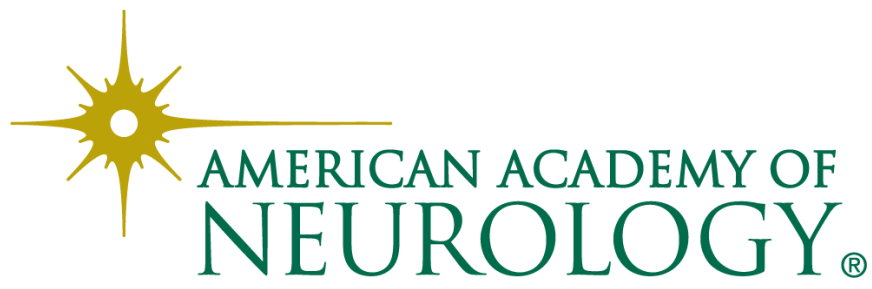

